\title{
ANALISIS NILAI KEMANUSIAAN PADA FILM MELUKIS KAKI LANGIT KARYA GIRRI PRASETYO
}

\author{
Irwan Soulisa \\ Universitas Victory Sorong \\ soulisairwan@gamil.com
}

\begin{abstract}
Abstrak
Penelitian mengenai nilai-nilai kemanusiaan didalam film menceritakan seorang anak yang hanya tinggal bersama dengan ibunya, setelah mereka kehilangan orang yang mereka cintai (ayahnya). Suatu ketika mereka harus kembali ke kampung halaman ayahnya di Lombok untuk melanjutkan kehidupan mereka. mendorong. Rumusan penelitian bagaimana nilai kemanusiaan dalam film Melukis Kaki Langit Karya Giri Prasetyo?. Tujuan untuk mendeskripsikan Nilai Kemanusian dalam film Melukis Kaki Langit” Karya Giri Prasetyo. Teori yang digunakan Menurut Nurgiyantoro, Nilai-nilai kebenaran sama dengan nilai kemanusiaan, dan teori Sada mengemukakan nalai-nilai kemanusiaan adalah unik untuk umat manusia dan bukan untuk binatang,dan nilai-nilai kemanusiaan haruslah Universal. Metode yang digunakan deskriptif kualitatif. Data dalam penelitian ini adalah kata-kata yang berbentuk dialog yang terdapat dalam film "Melukis Kaki Langit"Karya Giri Prasetyo. Sedangkan sumber data dari film Melukis Kaki Langit Karya Giri Prasetyo yang berdurasi 1 jam-14 menit- 08 detik,yang diliris pada tahun 2013. Teknik pengumpulan data menonton secara keseluruhan film melukis kaki langit. Selain itu juga peneliti menonton secara berulang-ulang dan mencatat hal-hal yang penting dalam menganalisis film. Teknik analisa data meliputi tiga komponen yaitu (1) Reduksi,(2) Penyajian data,(3) Penarikan kesimpulan. Hasil penelitian nilai kebenaran, nilai cinta kasih, nilai kepedulian, nilai tolong menolong, nilai tampa kekerasan.
\end{abstract}

Kata Kunci: Nilai Kemanusiaan, Film, Melukis Kaki Langit Karya.

Abstrac

Research on human values in the film tells of a child who only lives with his mother, after they lose their loved one (his father). One day they had to return to their father's hometown in Lombok to continue their life. push. The research formulation is what is the human value in the film Melukis Kaki Langit by Giri Prasetyo?. The aim is to describe the value of humanity in the film Melukis Kaki Langit" by Giri Prasetyo. The theory used According to Nurgiyantoro, truth values are the same as human values, and Sada's theory suggests that human values are unique to human beings and not to animals, and human values must be universal. The method used is descriptive qualitative. The data in this study are words in the form of dialogue contained in the film "Melukis Kaki Langit" by Giri Prasetyo. While the data source is from Giri Prasetyo's film Painting the Skyline, which has a duration of 1 hour-14 minutes-08 seconds, which was released in 2013. The data collection technique is watching the whole film painting the skyline. In addition, the researcher watched repeatedly and noted important things in analyzing the film. Data analysis techniques include three components, namely (1) reduction, (2) data presentation, (3) drawing conclusions. The results of the research are the value of truth, the value of love, the value of caring, the value of helping, the value of being without violence.

Keywords: Human Values, Film, Painting the Skyline. 


\section{PENDAHULUAN}

Karya sastra adalah kreatvitas seseorang terhadap ide,perasaan,dan pikiran yang di milikinya.Karya sastra merupakan hasil imajinasi manusia yang mengambil kehidupan manusia sebagai sumber inspirasinya.Inspirasi dalam karya sastra adalah imajinasi yang berdasarkan kenyataan. Imajinasi tersebut juga di imajinasikan oleh orang lain. Menurut Teew,(2010 :13) Sastra sebagai sebuah karya cipta atau fiksi yang bersifat imajinasi, atau sastra adalah penggunaan bahasa yang indah dan berguna untuk menandakan hal-hal lain.Karya sastra bukan hanya pengalaman yang dituangkan dalam sebuah tulisan atau sebuah karya fiksi,tetapi juga mengandung unsure seni dan keindahan yang dirangkai dengan realitas kehidupan, karena karya sastra menceritakan berbagai masalah, kehidupan manusia dalam interaksinya dengan lingkungan dan sesama,dan juga interaksi dengan diri sendiri dan Tuhan.

Namun, Karya sastra juga merupakan media yang digunakan oleh pengarang dalam menyampaikan gagasan-gagasannya.Sebagai media,karya sastra menjadi jembatan yang menghubungkan pikiran-pikiran pengarang,yang disampaikan kepada pembaca .Dalam karya sastra diciptakan bukan sekedar untuk menghibur pencinta sastra tetapi bermaksud untuk menyampaikan, ide, perasaan, pengalaman, serta tanggapan hidup disekitarnya dengan cara yang menarik dan juga menyenangkan.karena itulah karya sastra diciptakan karena memilki tujuan tertentu.Sebuah karya sastra yang diciptakan harus mengandung cerita yang menarik, memiliki bahasa yang indah,dan memiliki unsur pembangun bahkan nilai-nilai yang terkandung di dalam sebuah karya sastra .

Dunia kesusastraan juga mengenal karya sastra berdasarkan cerita atau realita yang merupakan bentuk dan hasil sebuah pekerjaan kreatif yang pada hakikatnya adalah suatu media yang mendayagunakan bahasa untuk mengungkapkan mengenai kehidupan manusia. Salah satunya adalah film yang dikategorikan sebagai karya seni berupa sandiwara atau drama.Film merupakan produk dari media massa yang sangat popouler. Film juga merupakan media hiburan yang mempunyai tempat tersendiri bagi khalayak dibandingkan dengan media massa yang lain. Film tidak hanya memiliki alur cerita yang menarik, namun juga memiliki gambar dan efek suara yang dapat menciptakan suasana bagi penonton sehingga film tidak pernah bosan untuk dinikmati. Film tidak hanya sebagai media hiburan semata, tetapi juga sebagai media informasi. Film sendiri adalah hasil cipta seseorang dalam bentuk karya seni yang memiliki kelengkapan dari beberapa unsure seni,yang ditampilkan dalam bentuk gambar dan suara yang dibuat sedemikian rupa,dengan permainan kamera, teknik editing, dan scenario yang ada dan juga film sering disebut movie, secara kolektif, sering disebut sinema.

Film sebagai alat untuk menyampaikan berbagai pesan kepada khalayak melalui sebuah media cerita. Film juga merupakan medium ekspresi artistik sebagai suatu lat para seniman dan insane perfilman dalam rangka mengutarakan gagasan-gagasan dan ide cerita secara esnsial dan substansial film memiliki power yang akan berimplikasi terhadap komunikan masyarakat (Wibowo, 2007 196). Film diciptakan tidak hanya untuk menjadi hiburan semata, tetapi film yang dipertontonkan atau di publikasikan merupakan gambaran hidup seseorang yang dituangkan dalam sebuah film.untuk itu film yang dipublikasikan tidak terlepas dari nilai-nilai yang terkandung didalam karya seni yang berupa film itu.Salah satunya adalah nilai kemanusiaan yang menjadi subjek dalam penelitian ini. 
Nilai merupakan keyakinan dalam menentukan pilihan yang mempengaruhi manusia dalam setiap tindakan yang dilakukan.Kluckhohn (Brameled,Via Mulyana, 2004), mendefenisikan nilai sebagai konsepsi (tersirat atau terrsurat yang sifatnya membedakan ciriciri individu atau kelompok) dari apa yang diinginkan yang mempengaruhi pilihan terhadap cara,tujuan antara tujuan akhir tindakan.Nilai adalah rujukan atau keyakinan dalam menentukan pilihan.

Nilai kemanusiaan adalah nilai mengenai harkat dan martabat manusia.Manusia merupakan makhuk yang paling tertinggi diantara ciptaan Tuhan. Seseorang mempunyai nilai kemanusian yang tinggi mengkehendaki masyarakat yang memiliki sikap dan perilaku layaknya disebut manusia. Nilai kemanusiaan merupakan nilai-nilai yang sifatnya Universal dan dapat di kembangkan untuk membentuk karakter manusia. Nilai kemanusiaan adalah nilai yang menyangkut kelakuan dan perbuatan manusia yang sesuai dengan norma dan menghormati martabat manusia (Koentjoroningrat).

Berdasarkan pernyataan di atas, peneliti tertarik untuk Menganalisis Nilai Kemanusian dalam film "Melukis Kaki Langit" karya Giri Prasetyo, karena film ini merupakan film yang menarik perhtian penonton dan termaksud film dengan nilai kemanusiaan yang menarik untuk dianalisis. Peneliti memilih film "Melukis Kaki Langit" Karya Giri Prasetyo sebagai sumber penelitian,karena film ini menceritakan tentangseorang anak yang hanya tinggal bersama dengan ibunya, setelah mereka kehilangan orang yang mereka cintai (ayahnya). Suatu ketika mereka harus kembali ke kampung halaman ayahnya di Lombok untuk melanjutkan kehidupan mereka. Di Lombok mereka memiliki perpustakaan keliling yang difasilitsi oleh Menteri Lombok.dalam hari-hari hidup mereka di Lombok Ara selalu meghabiskan waktunya bersama dengan anak-anak di kampung Lombok, bermain bersama, bahkan Ara membagikan ilmu yang dimilikinya kepada mereka semua. Perpustakaan keliling yang difasilitasi oleh menteri Lombok, sangatlah terbatas sehingga rumah Ara menjadi tempat untuk membaca dikarenakan Ara memiliki buku yang banyak untuk dibaca. Sola adalah teman kecil Ara yang usianya masih kecil, Ara sudah mengganggap Sola sendiri sebagai adiknya. Sola tidak bersekolah seperti teman-teman seusianya di karenakan kehidupan ekonomi keluarganya yang tidak cukup untuk membiayai Sola bersekolah.sikap tolong menolong selalu diterapkan oleh ara dan ibunya. Ara dan Sola selalu menghabiskan waktu bersama,sampai suatu ketika kejadian yang tidak diinginkan menimpa keluarga sola. Rumah sola kebakaran,nyawa Sola dalam masih dipertaruhkan,karena sola menjadi korban kebakaran itu,untung saja nyawa sola bisa diselamatkan, dan hari-hari Ara dan sola kembali berwarana seperti sebelumnya. Kasih sayang, dan kepedulian yang selalu terbangun membuat semuanya menjadi berwarna seperti disetiap Kaki Langit.

Film "Melukis Kaki Langit" adalah sebuah film yang disutradarai oleh Giri Prasetyo.Giri Prasetyo adalah seorang sutrada muda yang terkenal dengan kemampuan yang dimilikinya,Giri adalah seorang pemuda yang merupakan lulusan SMA Negeri 2 Madium .Giri adalah seorang sutrdara untuk karya-karya film fiksi,film documenter, iklan TV, iklan digital, dan beberapa karya audiovisual lainnya. Giri Prsetyo juga seorang pedongeng. Diawal kariernya Giri mulai belajar menjadi seorang fotografi dan belajar menangkap visual apapun didepan matanya, sehingga dapat menciptakan dan menceritakan dari dunia dan perspektifnya sendiri. Dari kegigihannya dan semangatnya untuk terus belajar membuat apa yang dicita- 
citakan oleh Giri kini membuat dirinya dapat merealisasikan mimpinya untuk menjadi seorang sutradara( pembuat film). Mimpinya telah mengantarkannya melahirkan sebuah film terbaru yang berjudul "Melukis Kaki Langit" yang diriiskan pada September 2013.

Hasil analisis Film melukis kaki langit ini dapat peneliti mengidentifikasi hal-hal yang terkait dengan nilai kemanusiaan yang diperankan oleh masing-masing tokoh tersebut. Selanjutnya tujuan dari penelitian ini untuk mendeskripsikan Nilai Kemanusian dalam film "Melukis Kaki Langit" Karya Giri Prasetyo, serta metode yang digunakan dalam penelitian ini adalah metode deskriptif kualitatif.

\section{KAJIAN TEORI}

Karya sastra tidak pernah terlepas dari nilai-nilai yang menjadi salah satu tolak ukur dalam sebuah karya sastra. Begitupun Keberadaan nilai kemanusiaan tidak terlepas dari pandangan pengarang, tentang nilai-nilai kebenaran yang menjadi ajaran bagi kehidupan pengarang bahkan kehidupan pembaca .Sehingga dapat menjadi petunjuk sesuai dengan pandangan pengarang. Dalam penelitian ini peneliti menggnakan teori menurut Nurgiyantoro, (2010:320) Nilai-nilai kebenaran sama dengan nilai kemanusiaan, yaitu sifat-sifat (hal-hal) penting atau berguna dalam kehidupan pada nilai kebenaran, nilai cinta kasih, nilai kepedulian, nilai tolong menolong, nilai tampa kekerasan.

Selain itu, Sada (2011:6) mengemukakan nalai-nilai kemanusiaan (Human Values) mempunyai kata Manusia yang berarti bahwa nilai-nilai ini adalah unik untuk umat manusia dan bukan untuk binatang, dan nilai-nilai kemanusiaan haruslah Universal yang artinya tidak bergantung pada ras, kelompok, tradisi, dan kebudayaan. Oleh karena itu, nilai-nilai kemanusiaan adalah nilai-nilai yang harus dipahami dan diamalkan oleh seluruh umat manusia sesuai dengan kerangka berfikir yang dirancang oleh peneliti dalam penelitian ini..

\section{METODE PENELITIAN}

Penelitian dengan judul "Analisis Nilai Kemanusiaan dalam film Melukis Kaki Langit Karya Giri Prasetyo" menggunakan metode penelitian deskriptif kualitatif dan jenis penelitiannya adalah pendekatan sosiologi sastra, karena data yang diambil berupa kata-kata yang digunakan untuk mendeskripsikan nilai kemanusiaan.Penelitan kualitatif adalah prosedur penilaian yang menghasilkan data deskriptif berupa kata-kata tertulis atau lisan dari orang dan perilaku yang dapat diamati (Suwardi,2003: 62). Data yang digunakan dalam penelitian ini adalah kata-kata yang berbentuk dialog yang terdapat dalam film "Melukis Kaki Langit"Karya Giri Prasetyo. Sedangkan sumber data dalam penelitian ini bersumber dari film Melukis Kaki Langit Karya Giri Prasetyo yang berdurasi 1 jam-14 menit- 08 detik,yang diliris pada tahun 2013.

Teknik pengumpulan data yang digunakan dalam penelitian ini adalah menonton secara keseluruhan film melukis kaki langit .Selain itu juga peneliti menonton secara berulang-ulang dan mencatat hal-hal yang penting dalam menganalisis film. Adapun langkahlangkah pengumpulan data yang dilakukan dalam penelitian ini sebagai berikut :

1) Menonton film Melukis Kaki Langit karya Giri Prasetyo

2) Mencatat beberapa hal yang menjadi tujuan dalam penelitian. 
Teknik analisa data yang digunakan dalam penelitian ini meliputi tiga komponen yaitu (1)

Reduksi, (2) Penyajian data,(3) Penarikan kesimpulan.

\section{Reduksi Data}

Pada langkah ini data yang diperoleh dicatat dalam uraian yng terperinci. Dari data-data yang sudah dicatat tersebut,kemudian dilakukan penyerdehanaan data.Data-data yang dipilih hanya data yang berkaitan dengan masalah yang akan dianalisa dalam penelitian.

\section{Penyajian Data}

Pada langkah ini data-data yang sudah ditetapkan disusun secara rapi agar mudah dipahami. Data -data tersebut kemudian di analisa sehingga diperoleh deskripsi tentang nilai kemanusiaan pada film melukis kaki langit.

3.Penarikan kesimpulan

Pada tahap ini dibuat kesimpulan dari data-data yang diperoleh sejak awal penelitian.Kesimpulan ini masih memerlukan verifikasi (penelitian kembali tentang kebenaran laporan) sehingga hasil yang diperoleh benar-benar valid.

\section{HASIL DAN PEMBAHASAN}

\subsection{Hasil}

Berikut hasil penelitian berdasarkan teori-teori yang sudah ditetapkan sebelumnya.

4.1.1 Nilai Kebenaran adalah sesuatu yang tidak berubah dan bersifat kekal.Kebenaran diungkapkan dan dinyatakan melalui berbagai jalur,namun kebenaran itu hanya satu.Unsur-unsur nilai kebenaran anatra lain,selalu ingin tahu,tidak diskriminasi,intuisi,mencari pengetahuan,suka terhadap kebenaran.

4.1.2 Nilai Kedamaian merupakan kebutuhan di dalam diri seseorang. Apabila ia tidak memiliki kedamaian maka yang ada adalah kegelisahan. Penyesuaian atas pengarahan yang dilakukan oleh seseorang atau kelomok untuk menjaga keseimbngan kehidupan.

4.1.3 Nilai cinta Kasih adalah belas kasih murni yang memotivasi tanpa pamrih demi kebaikan orang lain.Cinta ksih bukan sekedar perasaan emosi,tetapi sesuatu yang lebih mendalam dan lebih mensar dari hakekat manusia.Dalam sejarah umat manusia,cinta memang peranan yang utama dalam menyatuhkan keagaman yang ada.Cinta bukan hanya dimiliki oleh manusia,namun cinta juga dimiliki oleh seluruh makhul hidup di dunia ini.Sama halnya dengan cinta kasih yang diberikan Ara kepada Sola meskipun Sola bukan siapasiapanya Ara.

4.1.4 Nilai Perilaku Yang Baik adalah sikap atau perbuatan yang tidak merugikan orang lain, namun justru sesuai dengan budi luhur, perilaku tidak dapat dilepaskan dan kaitannya dengan sikap sebaliknya dapat dikemukakan bahwa sikap berkaitan dengan tujuan mematuhi kecenderungan-kecenderungan perilaku segala sikap ucapan dan perbuatan yang baik.

4.1.5 Nilai Tanpa Kekerasan adalah wujud dari sikap taat dan menghormati hukum alam, hukum dan peraturan.Nilai tanpa kekerasaan merupakan cerminan wujud 
daripada moralitas dan integritas sehingga perdamaian dunia dan keharmonisan akan tercapai apabila etika taanpaa kekerasan dapat diwujudkan dlam kehidupan dunia.Unsur-usur nilai tanpa kekerasaan adalah kesadaran akan tanggung jawab,kasih sayang,suka menolong dan keadilan .

\section{Tabel 4.1 hasil penelitian nilai-nilai kemanusia berdasarkan teori}

\begin{tabular}{|c|c|c|c|c|}
\hline $\begin{array}{l}\mathbf{N} \\
\mathbf{0}\end{array}$ & $\begin{array}{l}\text { Wujud nilai } \\
\text { kemanusiaan }\end{array}$ & Unsur Nilai & Deskripsi & Durasi \\
\hline \multirow[t]{2}{*}{1} & \multirow[t]{2}{*}{ Kebenaran } & $\begin{array}{l}\text { Mencari } \\
\text { pengetahuan }\end{array}$ & $\begin{array}{l}\text { 1.Sola mengejar perpustakaan } \\
\text { keliling untuk membaca } \\
\text { 2.Ketika sedang makan bersama } \\
\text { dengan ibunya,ara menceritakan } \\
\text { kegiatan hari pertamanya di sekolah } \\
\text { 3.Ibu mimin,membantu ara dengan } \\
\text { ibunya untuk memberikan ilmu yang } \\
\text { dimiliki oleh ibu mimin kepada } \\
\text { warga Lombok yang tidak tahu } \\
\text { membaca } \\
\text { 4.Hari-hari ara dan sola tak hanya } \\
\text { bermain bersama,tetapi mereka juga } \\
\text { bersama-sama menyaksikan } \\
\text { kebudayaan yang dipertunjukan oleh } \\
\text { warga Lombok } \\
\text { 5.Gubenur Lombok memfasilitasi } \\
\text { kota Lombok dengan memberikan } \\
\text { perpustakann keliling,Tak hanya itu } \\
\text { anak-anak di Lombok sering } \\
\text { membaca diperpustakaan itu. } \\
\text { 6.Ara selalu membagikan ilmu yang } \\
\text { dimilikinyaa dengan anak-anak } \\
\text { dilombok dan belajar bersama }\end{array}$ & $33: 16$ \\
\hline & & $\begin{array}{l}\text { Tindak } \\
\text { Diskriminasi }\end{array}$ & $\begin{array}{l}\text { 1.Ketika sedang membereskan } \\
\text { pekerjaan di rumah ara,para preman } \\
\text { Lombok datang dan mengganggu } \\
\text { pekerjaan mereka,dan maming samu } \\
\text { datang dan menghampiri mereka dan } \\
\text { bermaksud untuk melarang } \\
\text { mereka,tetapi hal ini membuat } \\
\text { mereka menjadi berkelahi }\end{array}$ & $59: 51$ \\
\hline \multirow[t]{2}{*}{2} & \multirow[t]{2}{*}{ Kedamaian } & Disiplin diri & & \\
\hline & & Ketabahan & $\begin{array}{l}\text { 1.Ara dan ibunya mulai beradaptasi } \\
\text { dengan kota lombok,bahan berbaur } \\
\text { dengan orang-orang disekitarnya ,dan } \\
\text { kini mulai menerima kepergian orang } \\
\text { yang mereka sayang }\end{array}$ & 1:14:08 \\
\hline 3 & Cinta kasih & Peduli dan empati & $\begin{array}{l}\text { 1.Ketika ara pulang sekolah,ara } \\
\text { bertemu dengan sola dan } \\
\text { menanyakan keadaan sola,dan } \\
\text { menawarkan bantuan kepada sola } \\
\text { untuk menemaninya }\end{array}$ & $52: 40$ \\
\hline
\end{tabular}




\begin{tabular}{|c|c|c|c|c|}
\hline & & $\begin{array}{l}\text { Peduli dan kasih } \\
\text { sayang }\end{array}$ & $\begin{array}{lcr}\text { 1.Setelah sola diselamatkan } & \text { dari } \\
\text { kebakaran itu,maming samu } \\
\text { menangisi } & \text { sola dan segera } \\
\text { membawanya ke rumah sakit } & \end{array}$ & $1: 07: 59$ \\
\hline & & Peduli & 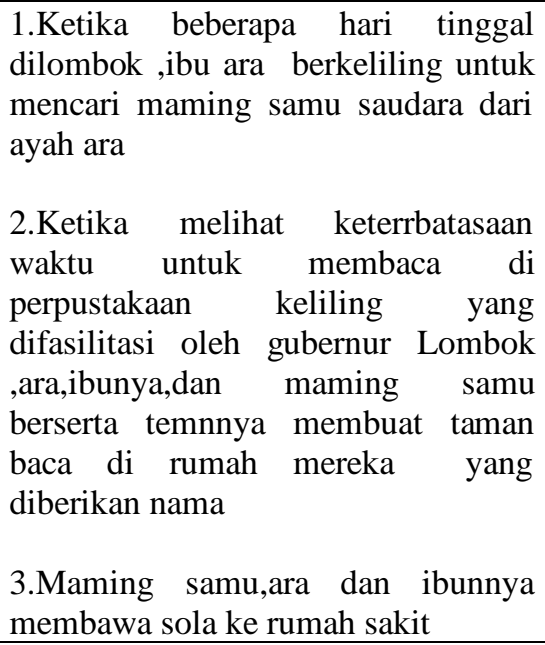 & $26: 46$ \\
\hline & & Empati & $\begin{array}{l}\text { 1.Setelah sekian llama mencari } \\
\text { mencari maming samu,akhirnya ara } \\
\text { dan ibunya menemukan maming } \\
\text { samu dan mengajaknya pulang } \\
\text { bersama mereka,karena maming } \\
\text { samu tidak memiliki tempat tinggal }\end{array}$ & $40: 57$ \\
\hline \multirow[t]{2}{*}{4} & \multirow[t]{3}{*}{$\begin{array}{l}\text { Perilaku } \\
\text { benar }\end{array}$} & Semangat juang & $\begin{array}{l}\text { 1.Teman lama maming,memberikan } \\
\text { semangat untuk ibunya ara,untuk } \\
\text { tetap semangat mencari maming dan } \\
\text { tidak mudah menyerah }\end{array}$ & $35: 14$ \\
\hline & & $\begin{array}{l}\text { Pelayanan } \\
\text { terhadap orang } \\
\text { lain }\end{array}$ & $\begin{array}{l}\text { 1.Ibu mimin,membantu ara dengan } \\
\text { ibunya untuk memberikan ilmu yang } \\
\text { dimiliki oleh ibu mimin kepada } \\
\text { warga Lombok yang tidak tahu } \\
\text { membaca } \\
\text { 2.Tim medis (RS) segera membantu } \\
\text { sola yang menjadi korban kebakaran } \\
\text { untuk dilarikan ke rumah sakit }\end{array}$ & $1: 08: 43$ \\
\hline & & Kebersihan & $\begin{array}{l}\text { 1.Setelah pindah dari Jakarta ke } \\
\text { Lombok,ara dan ibunya } \\
\text { membersihkan rumah mereka yang } \\
\text { sekarang akan menjadi tempat } \\
\text { tinggal mereka. }\end{array}$ & $14: 20$ \\
\hline \multirow[t]{2}{*}{5} & \multirow[t]{2}{*}{ Tanpa kekerasan } & $\begin{array}{l}\text { Mempertimbangka } \\
\mathrm{n} \text { oranglain }\end{array}$ & $\begin{array}{l}\text { 1.Warga Lombok membantu } \\
\text { memadamkan api yang sempat } \\
\text { membuat rumah sola terbakar dan } \\
\text { meyelamatkan sola dari kebakaran } \\
\text { itu }\end{array}$ & 1:06:30 \\
\hline & & Suka menolong & $\begin{array}{l}\text { 1.Setelah berhari-hari } r \\
\text { maming samu,ara dan ibunya } \\
\text { bertemu dengan teman lama maming } \\
\text { samu,dan kemudian teman lama } \\
\text { samu membantu mereka untuk } \\
\text { mencari maming samu } \\
\text { 2.Ketika maming samu dan ibu ara } \\
\text { sedang berpergian,di tengah } \\
\text { perjalanan mereka membantu para }\end{array}$ & $56: 59$ \\
\hline
\end{tabular}




\subsection{PEMBAHASAN}

Adapun pembahasan dalam penelitian ini antara lain sebagai berikut:

\subsubsection{Wujud Nilai Kemanusiaan dalam Kebenaran}

\section{Mencari Pengetahuan}

Pengetahuan merupakan hasil dari tahu dan in setelah orang melakukan pengindraan terhadap objek tertentu (Notoatmodjo 2007). Berdasarkan teori di atas dapat diuraikan bahwa Mencari pengetahuan adalah proses dimana seseorang mencari ilmu,penegtahuan sendiri adalah segala apa yang kita ketahui dan merupakan suatu yang baru terhadap suatu objek dengan pengamatan akal dan pikiran.

”Abang Rari!!! ,Kamu lagi-kamu lagi ,aku mau baca buku.Biasanya juga begitu”

"Ara jadi gimana,hari pertama kamu sekolah anak gede?,Biasa aja ma,tidak bedah jauh dengan Jakarta.

"Pada suatu hari Ara dan sola bersama teman-temannya sedang belajar,!! "Wahai rakyat jelata,Robbinhot telah tiba,!hallo! diujung jalan hiduplah seorang yang bernamarobbinhot."

Pada kutipan di atas dapat dilihat kalau Sola memiliki prinsip yang kukuh untuk tetap mencari pengetahuan,meskipun Sola sering diusir,setiap kali ingin membaca.dan sikap ara selalu ingin membagi ilmu yang dimilikinya kepada anak-anak di Lombok.

\section{Tindak Diskriminasi}

Diskriminasi adalah pelayanan yang tidak adil terhadap individu tertentu.Istilah diskriminasi berasal dari bahasa latin yaitu "Discriminatus"yang artinya membagi atau membedakan.istilah ini biasanya ditunjukan untuk melukiskan,suatu tindakan dari pihak mayoritas yang dominan yang lemah,sehingga dapat dikatakan bahwa perilaku mereka itu bersifat tidak bermoral dan tidak demokrasi.

Menurut Liliweri (2005) ,diskriminasi adalah perilaku yang ditunjukan untuk mencegah suatu kelompok,atau membatasi kelompok lain yang berusaha memiliki atau mendapatkan mendapatkan sumber daya. Diskriminasi apat dilakuan melalui kebijakan untuk mengurangi ,memusnahkan, menaklukan, memindahkan, melindungi secara legal, menciptakan plurarisme budaya dan mengasimilasi kelompok lain.

\subsubsection{Wujud Nilai Kemanusiaan Dalam Kedamaian}

\section{Disiplin Diri}

Disiplin diri adalah perilaku yang bisa dipelajari.Disiplin diri dapat dibentuk dengan latihan-latihan dan pengulangan dalam kehidupan sehari-hari, membiasakan kebiasaan yang baik,mengurangi kebiasaan yang buruk, membuat perubahan sederhana.Disiplin merupakan sikap yang selalu menepati janji, sehingga orang lain akan percaya.Istilah disiplin adalah dari bahasa latin "Discere" yang berarti belajar. 


\section{Ketabahan}

Ketabahan merupkan sebuah proses kekuatan jiwa seseorang.Ketabahan bukan saja proses yang identik dengan kemiskinan, tetapi dalam arti luas bisa berarti tabah menghadapi penderitaan.

"Ada kekuatan-kekuatan dasyat yang tak terduga yang timbul dari samudera,dan gunung berapai dan pada pribadi yang tahu benar.Meskipun ayah pergi aku dan mama terus berbaur dengan lingkungan sekitar,menjalma menjadi kain yang saling menjaga dan melindungi,terimkasih mama yang telah membawaku ke tempat ini.",

Berdasarkan kutipan diatas dapat kita lihat bahwa ara dan ibunya sudah bisa mengihklasan kepergian orang yang mereka sayangi dan dapat beradaptasi dengan lingkungan disekitar.

\subsubsection{Wujud Nilai Kemanusiaan Dalam Cinta Kasih}

\section{Peduli dan Empati}

Peduli dan Empati adalah sebuah nilai dasar dan sikap meperhatikan dan bertindak proaktif terhadap suatu kondisi atau suatu keadaan disekitar kita .

"Sola? Kamu kemana aja beberapa hari ini nggak kelihatan dirumah? Banyak kiriman loh,buku baru dan computer,itu apa kak? Bentuknya kotak,kamu bisa ketik banyak hal disana,kamu pasti senang deh,Tapi.... Emak lagi sakit kak,Sola harus menjaga emak,ka ara temani mau?,nggak usah dek kak ara terimaksih."

Berdsarkan kutipan di atas Nilai Peduli dan Empati adalah dimana ara merasa peduli kepada Sola ketika ia tidak kelihatan dan beberapa hari tidak bermain dan membaca buku di rumah ara.dan merasa empati ketika ara mengetahui ibu sola sedang sakit.

\section{Peduli dan Kasih Sayang}

Peduli dan kasih sayang adalah salah satu nilai yang saling berkaitan.

"Setelah Sola diselamatkan, dari kebakaran itu Maming Samu menangisi Sola dan segera membawanya ke Rumah Sakit”.

Nilai peduli dan kasih sayang pada kutipan diatas adalah ketika rumah sola kebakaran dan diselamatkan oleh warga,kemudian maming samu menghampirinya dan menangisi sola kemudian membawanya ke rumah sakit.

\section{Peduli}

Kepedulian adalah menjadikan diri kita terkait dengan orang lain dan apapun yang terjadi terhadap orang tersebut.Orang yang mengutamakan kebutuhan dan perasaan orang lain daripada kepentingannya sendiri adalah orang yang peduli.

Berdasarkan penelitian di atas daapat disimpulkan bahwa Peduli adalah sebuah nilai dasar dan sikap memperhatikan dan bertindak proaktif terhadap kondisi atau keadaan 
disekitar kita.Peduli adalah sebuah keberphakan kita untuk melibatkan diri dalam persoalan ,keadaan,atau kondisi yang terjadi di sekitar.

"Sola? Kamu kemana aja beberapa hari ini nggak kelihatan dirumah? Banyak kiriman loh,buku baru dan computer,itu apa kak? Bentuknya kotak,kamu bisa ketik banyak hal disana,kamu pasti senang deh,Tapi.... Emak lagi sakit kak,Sola harus menjaga emak,ka ara temani mau?,nggak usah dek kak ara terimakasih."

Berdasarkan kutipan di atas Nilai Peduli dan adalah dimana ara merasa peduli kepada Sola ketika ia tidak kelihatan dan beberapa hari tidak bermain dan membaca buku di rumah ara.

\section{Empati}

Empati adaah kemampuan seseorang untuk dapat mengerti perasaan dan emosi orang lain,dan juga kemampuan untuk membayangkan diri sendiri ditempat orang lain dan menghayati pengalaman orang tersebut.

Berdasarkan penelitian di atas dapat disimpulkan bahwa empati adalah suatu perasaan dimana seseorang benar-benar tahu dan mengerti bagaimana dari suatu kejadian yang dialami orang lain,karena ia perna mengalami atau berada pada posisi yang sama.

"Sekarang maming mau pulang kemana?,saya juga tidak tahu mau pulang kemana,saya tidak punya tempat tinggal.Maming ikut saya saja,mau?ayo maming kita pulang ,kerumah kita."

Nilai empati pada kutipan di atas adalah ketika maming samu telah ditemukan oleh ara dan ibunya,kemudian mereka mengajaknya pulang dan tinggal bersama mereka ketika mengetahui maming samu tidak memiliki tempat tinggal.

\subsubsection{Wujud Nilai Kemanusiaan Dalam Perilaku Yang Benar \\ 1. Semangat juang}

Semangat juang adalah satu nilai yang tumbuh dalam diri atau kemauan seseorang untuk melakukan sesuatu hal yang diinginkannya.

"Sabar nak,jangan menyerah,maming yakin kok,maming samung juga pasti akan menunggu kalian.Atau kita cari saja ke peabuahan besar,maksud kamu pelabuhan kapal? Ayo kita coba cari kesana ,jik tidak ada kita akhiri percrian kita hari ini."

Pada kutipan diatas dapat dilihat bahwa,nilai semangat juang diberikan oleh teman lama maming samu untuk ibunya ara,karna hampir menyerah dalam pencarian maming samu. 
2. Pelayanan terhadap orang lain

Pelayanan adalah sebuah proses pemenuhan kebutuhan melalui aktifitas orang lain yang menyangkut segala masalah yang ditunjukan orang lain untuk menyelesaikan masalah.

Berdasarkan hasil teori di atas dapat disimpulkan bahwa pelayanan terhadap orang lain adalah salah satu wujud nilai kemanusiaan yang menyangkut pelayanan terhadap orang lain.

"Ibu-ibu,besok sudah harus tahu membaca ya,nanti kalau jadi TKW,sudah bisa baca kontrak kerjanya."

Nilai pelayanan terhadap orang lain dapat dilihat dalam kutipan di atas adalah, ketika ibu marni, memberikan pelayanan berupa tenaganya dalam mendidik ibu-ibu di Lombok dalam membaca.

\section{Kebersihan}

Menurut Kamus Besar Bahasa Indonesia (KBBI) Keadaan yang bebas dari kotoran,termasuk diantaranya diantranya,debus sampah dan bau.

Berdasarkan teori di atas dapat disimpulkan bahwa,kebersihan adalah salah satu tanda dimana seseorang berada paa keadaan yang baik atau sebuah ceminan bagi setiap individu dalam menjaga kesehatan yang sangat penting dalam kehidupan sehari-hari.

“Ibu Ara membersihan rumah baru mereka di Lombok.

Pada kutipan diatas nilai kebersihan adalah ketika ibunya ara membersihkan rumah barunya mereka di Lombok.

\subsubsection{Wujud Nilai Kemanusiaan Tanpa kekerasan}

1. Mempertimbangkan oranglain

Suatu nilai kemanusiaan yang saling memikirkan keadaan orang lain, dengan kata lain tidak egois dan selalu bertindak dengan keputusan bersama.

“Warga Lombok menyelamatkan Sola ketika rumahnya terbakar. “

Nilai mempertimbangkan orang lain pada kutipan di atas adalah ketika warga Lombok menyelamatkan sola ketika rumahnya kebakaran.

2. Suka menolong

Sikap suka menolong sangat berkaitan dengan sikap Rendah hati dan murah hati.Suka menolong adalah sikap yang selalu ingin berbagi dengan sesama.

"Tunggu sebentar kalian cari siapa tadi? maming ini siapa ya ? Saya, temannya saat remaja dulu dari orang yang tadi kalian cari.ibu ini siapa ?saya keponakannya !! Kalo 
begitu maming boleh ikut saya sebentar? Bisa!! bisa ya... soalnya saya mau TanyaTanya.“

Berdasarkan kutipan di atas dapat dilihat bahwa, sikap suka menolong sangat diterapkan oleh temannya maming samu ketika ibu ara sedang berusaha mencari maming samu.

\section{KESIMPULAN}

Berdasarkan hasil penelitian dan pembahasan terhadap film Melukis kaki langit karya Giry Prasetyo, dapat peneliti menyimpulkan hasil penelitian menunjukan bahwa nilai kemanusiaan, yang terkandung dalam film melukis kaki langit terdiri dari lima bagian, yaitu Nilai Kemanusiaan dalam kebenaran, Nilai kemanusiaan dalam kedamaian, Nilai kemanusiaan dalam cinta kasih, Nilai kemanusiaan dalam perilaku yang benar, nilai kemanusiaan tanpa kekerasan.

\section{DAFTAR PUSTAKA}

Allo, Liliweri. 2005. Komunikasi Antar Pribadi. Jakarta: Rineka cipta

Endarswara, Suwardi. 2003. Metodologi Penelitian Sastra: efistemologi, Model, Teori Dan Aplikasi. Yogyakarta:FBS UNY.

Giri Prasetyo, 2013. Melukis Kaki Langit. Jakarta: Bait Kata

Mulyana, 2004. Mengartikulasi Pendidikan Nilai. Bandung: Alfabeta

Nurginatoro, Burhan 2010. Penilaian Dalam Pembelajaran Bahasa Dan Sastra Yogyakarta: pustaka pelajar

Notoatmojo, 2007. Promosi Kesehatan Dan Ilmu Prilaku.Jakarta: Rineka

Sada, Clarry. 2011. Pembelajaran Nilai-Nilai Kemanusiaan http:/jhv.sagepub.com\&http://global research.ca/indekx.php?contex=viewarticle

Teew, 2010. Sastra Dan Ilmu Sastra, Pengantar Teori Sastra. Jakarta: Dunia pusat Jaya

Wiwobo, Fred. 2007. Teknik Produksi Telivisi. Yogyakarta: pinus book publisher 